KS. WOJCIECH GÓRALSKI

Wydział Prawa Kanonicznego

Uniwersytetu Kardynała Stefana Wyszyńskiego w Warszawie

\title{
POSŁUGA POKOJU SUMIEŃ ZADANIEM SĘDZIEGO. PRZEMÓWIENIE FRANCISZKA DO ROTY RZYMSKIEJ Z 29.01.2018 ROKU
}

Treść: Wprowadzenie. - 1. Sędzia ekspertem sumienia. - 2. Rola sumienia w wyborach narzeczonych. - 3. Potrzeba katechumenatu małżeńskiego. - 4. Troska o sumienia zadaniem wszystkich wiernych. - 5. Wymierzanie sprawiedliwości w sprawach małżeńskich sprawą sumienia. - Zakończenie.

\section{Wprowadzenie}

Z okazji inauguracji nowego roku sądowego Trybunału Roty Rzymskiej papież Franciszek przyjął 29 stycznia 2018 roku na audiencji w Sali Klementyńskiej Pałacu Apostolskiego Kolegium Prałatów Audytorów oraz pozostałych pracowników i adwokatów tegoż Trybunału, a także studentów Studium Rotalnego.

Po powitaniu wszystkich zgromadzonych i złożeniu życzeń wszelkiego dobra w nowym roku sądowych, Ojciec święty podjął wątek - jak to sam zaznaczył - dotyczący ważnego aspektu posługi sędziowskiej, jakim jest centralne miejsce sumienia każdego sędziego i sumienia osób, których sprawami sędzia się zajmuje1. W istocie

\footnotetext{
${ }^{1}$ Franciscus, La cura della coscienza cristiana [Discorso in occasione dell'inaugurazione dell'anno giudiziario del Tribunale della Rota Romana], „L'Osservatore Romano” 158 (2018), nr 23, s. 8; Tekst polski: 29 I [2018] - Przemówienie do członków Trybunału Roty Rzymskiej. Troska o chrześcijańskie sumienie, „L'Osservatore Romano” wyd. polskie 39 (2018), nr 3-4, s. 17-19.
} 
bowiem, podkreślił mówca, działalność sędziowska jawi się również jako posługa pokoju sumień i wymaga wykonywania jej z pełną sumiennością, jak dobrze wyraża to formuła, która obecna jest w wydawanych przez sędziów wyrokach: „dla zaradzenia sumieniu” (ad consulendum conscientiae lub ut consulatur conscientiae)2.

\section{Sędzia ekspertem sumienia}

Franciszek wyraża przekonanie, że gdy chodzi o orzekanie o nieważności lub ważności małżeństw sędziowie rotalni stają się w pewnym sensie ekspertami sumienia wiernych chrześcijan. Pełniąc taką rolę, są powołani do nieustannego przyzywania pomocy Bożej, aby z pokorą i należycie wypełniali poważne zadanie, jakie zostało im powierzone przez Kościół, i by w ten sposób ukazywali powiązanie między pewnością moralną, którą sędzia powinien uzyskać na podstawie faktów i dowodów (ex actis et probatis), a sferą swojego sumienia znaną jedynie Duchowi Świętemu i przez Niego wspieraną. Dzięki światłu Ducha, zwraca się do sędziów papież, jest wam dane realnie wkraczać w świętą przestrzeń sumienia wiernych. Czymś znamiennym jest, dodaje, że mająca swoją bogatą historię modlitwa $A d s u m u s^{3}$, która była odmawiana na początku każdej sesji

\footnotetext{
${ }^{2}$ Franciscus, La cura della coscienza cristiana, dok. cyt., s. 8.

${ }^{3}$ Modlitawa ta brzmi następująco: „Adsumus, Domine Sancte Spiritus, adsumus peccati quidem immanitate detenti, sed in nomine tuo specialiter congregati. Veni ad nos et esto nobiscum et dignare illabi cordibus nostris. Doce nos quid agamus, quo gradiamur et ostende quid efficere debeamus, ut, Te auxiliante, ibi in omnibus placere valeamus. Esto solus suggestor et effector iudiciorum nostrorum, qui solus cum Deo Patre et eius Filio nomen possides gloriosum. Non nos patiaris perturbatores esse iustitiae qui summam diligis aequitatem. Non in sinistrum nos ignorantia trahat, non favor inflectat, non acceptio muneris vel personae corrumpat. Sed iunge nos tibi efficaciter solius Tuae gratiae dono, ut simus in Te unum et in nullo deviemus a vero; quatenus in nomine Tuo collecti, sic in cunctis teneamus cum moderamine pietatis iustitiam, ut et hic a Te in nullo dissentiat sententia nostra et in futurum pro bene gestis consequamur praemia sempiterna. Amen". Modlitwa ta tradycyjnie otwiera zgromadzenia synodalne Kościoła łacińskiego. Pojawia się ona po raz pierwszy w Hiszpanii pod koniec VII w. Jako jej autora wielu uczonych wskazuje św. Izydora z Sewilli.
} 
Soboru Watykańskiego II, jest tak często wypowiadana w Waszym Trybunale ${ }^{4}$.

Sfera sumienia, kontynuuje Franciszek, była bardzo bliska ojcom ostatniego Synodu Biskupów i w sposób znaczący wybrzmiała w Adhortacji apostolskiej Amoris laetitia ${ }^{5}$. Wynikało to ze świadomości, jaka dojrzała u Następcy Piotra i u ojców synodalnych co do naglącej potrzeby wsłuchiwania się pasterzy Kościoła w wymogi i oczekiwania tych wiernych, którzy na długie lata uczynili własne sumienie głuchym i nieobecnym, a następnie zostali wsparci przez Boga i życie w odnalezieniu nieco światła, i zwrócili się do Kościoła, by otrzymać pokój sumienia.

\section{Rola sumienia w wyborach narzeczonych}

Ojciec święty zwraca następnie uwagę na decydującą rolę sumienia w trudnych wyborach, jakich mają dokonać narzeczeni, aby zaakceptować i budować związek małżeński, a więc rodzinę, zgodnie z planem Bożym. Kościół, niezwykle czuła matka, aby zaradzić sumieniu wiernych, którzy potrzebują prawdy, dostrzegł konieczność zachęcania osób pracujących w duszpasterstwie małżeństwa i rodziny do odnowienia świadomości $w$ dziedzinie pomagania narzeczonym w budowaniu i strzeżeniu wewnętrznego sanktuarium ich sumienia chrześcijańskiego. W tej sprawie, stwierdza Franciszek, pragnę zwrócić uwagę, iż w dwóch dokumentach wydanych w formie motu

\footnotetext{
${ }^{4}$ Franciscus, La cura della coscienza cristiana, s. 8.

${ }^{5}$,Świadomi wagi konkretnych uwarunkowań, możemy dodać, że ludzkie sumienie powinno być lepiej włączone do praktyki Kościoła w niektórych sytuacjach, które obiektywnie odbiegają od naszego rozumienia małżeństwa. Oczywiście musimy zachęcać do dojrzałości sumienia światłego, uformowanego, któremu towarzyszy odpowiedzialne i poważne rozeznanie pasterza i proponować coraz większe zaufanie do łaski. Sumienie może jednak uznać nie tylko to, że dana sytuacja nie odpowiada obiektywnie ogólnym postanowieniom Ewangelii. Może także szczerze i uczciwie uznać to, co w danej chwili jest odpowiedzią wielkoduszną, jaką można dać Bogu [...]”. Francesco, „Amoris laetitia”. Esortazione apostolica sull'amore nella familia, Città del Vaticano-Cinisello Balsamo 2016. Tekst polski: Oృcıec ŚwiĘTY Franciszek, Posynodalna Adhortacja Apostolska „Amoris laetitia” - o miłości w rodzinie, Kraków 2016, n. 303.
} 
proprio $^{6} \mathrm{w}$ przedmiocie procesu małżeńskiego zachęciłem do tego, by przeprowadzać dochodzenie duszpasterskie na szczeblu diecezji, tak aby nie tylko usprawnić proces, lecz także by uczynić go bardziej sprawiedliwym, przy należytej znajomości przyczyn i motywów będących u źródeł niepowodzenia małżeństwa. $Z$ drugiej strony, w adhortacji apostolskiej Amoris laetitia zostały wskazane sposoby duszpasterskie postępowania mające na celu niesienie pomocy narzeczonym w dokonywaniu bez lęków rozeznania i w konsekwencji wyboru przyszłego życia małżeńskiego i rodzinnego przez opisanie w pierwszych pięciu rozdziałach nadzwyczajnego bogactwa paktu małżeńskiego, zarysowanego przez Boga w Pismach i przeżywanego przez Kościół na przestrzeni dziejów ${ }^{7}$.

Ojciec Święty stwierdza następnie, że niezwykle potrzebne jest stałe doświadczenie wiary, nadziei i miłości, ażeby młodzi ludzie znów podejmowali decyzję z pewną i pogodną świadomością, że związek małżeński, otwarty na dar potomstwa, jest wielką radością dla Boga, dla Kościoła i dla ludzkości. Droga refleksji synodalnej nad małżeństwem i rodziną oraz powstała w rezultacie adhortacja apostolska Amoris laetitia miały wytyczony przebieg i cel: jak ocalić młodych ludzi przed ogłuszającym zgiełkiem i hałasem tego, co nietrwałe, co skłania ich do rezygnowania z podejmowania stałych i pozy tywnych zobowiązań dla dobra indywidualnego i zbiorowego. Jest to uwarunkowanie, które ucisza głos ich wolności, tej głębokiej

\footnotetext{
${ }^{6}$ Zob. Papież Franciszek, List apostolski motu proprio „Mitis Iudex Dominus Iesus", reformujacy kanony Kodeksu Prawa Kanonicznego dotyczace spraw o orzeczenie nieważności małżeństwa. List apostolski motu proprio „Mitis et misericors Iesus”, reformujący kanony Kodeksu Kanonów Kościołów Wschodnich dotyczące spraw o orzeczenie nieważności (tekst łacińsko-polski), Tarnów 2015, Zasady proceduralne, artt. 2-3 obu dokumentów.

${ }^{7}$ Franciscus, La cura della coscienza cristiana, s. 8; Zob. także Francesco, „Amoris laetitia”, rozdziały: I - W świetle Słowa; II - Rzeczywistość rodzin i wyzwania; III - Spojrzenie skierowane na Jezusa: powołanie rodziny; IV - Miłość w małżeństwie; V - Miłość, która staje się owocna.
} 
„komórki” - właśnie sumienia - którą tylko Bóg oświeca i otwiera na życie, jeżeli pozwoli Mu wejść 8 .

\section{Potrzeba katechumenatu małżeńskiego}

W dalszym fragmencie swojej alokucji Franciszek zwraca uwagę na cenną i zarazem pilną potrzebę podjęcia działalności całego Kościoła w dziedzinie odzyskiwania, zachowania i strzeżenia chrześcijańskiego sumienia oświecanego przez wartości ewangeliczne. Uznaje, że „będzie to przedsięwzięcie długotrwałe i niełatwe, wymagające od biskupów i kapłanów niestrudzonego działania na rzecz oświecenia, obrony i wspierania chrześcijańskiego sumienia naszych ludzi. Wypowiedzi, jakie padały na Synodzie Biskupów (z 2014 i 2015 roku) oraz posynodalna adhortacja apostolska Amoris laetitia zapewnily w ten sposób pierwszorzędny punkt: jest nim konieczna relacja między regułą wiary (regula fidei), czyli wiernością Kościoła nienaruszalnemu Magisterium w przedmiocie małżeństwa, podobnie w przedmiocie Eucharystii, a pilną potrzebą zwrócenia uwagi przez tenże Kościół na procesy psychologiczne i religijne u wszystkich osób powołanych do wyboru małżeńskiego i rodzinnego. Przychylając się do życzenia ojców synodalnych, Papież, jak zaznacza, miał już sposobność zalecenia podejmowania katechumenatu małżeńskiego [podkr. w tekście - W.G], rozumianego jako niezbędna droga młodych ludzi i par, mająca doprowadzić do ożywienia ich chrześcijańskiego sumienia, wspieranego łaską dwóch sakramentów - chrztu i małżeństwa""

\footnotetext{
${ }^{8}$ Franciscus, La cura della coscienza cristiana, s. 8.

9 "Questo è preziosa e urgente l'azione pastorale di tutta la Chiesa per il recupero, la salvaguardia, la custodia di una coscienza cristiana, illuminata dai valori evangelici ! Sarà un impresa lunga e non facile, che richiede a vescovi e presbiteri di operare indefessamente per illuminare, difendere e sostenere la coscienza cristiana della nostra gente. La voce sinodale dei Padri Vescovi e la succesiva Esortazione apostolica Amoris laetitia hanno così assicurato un punto primordiale: il necessario rapporto tra la regula fidei, cioè la fedeltà della Chiesa al magistero intoccabile sul matrimonio, così come sull'Eucaristia, e l'urgente attenzione della Chiesa stessa ai processi psicologici e religiosi di tutte le persone chiamate alla scelta matrimoniale e familiare. Accogliendo gli auspici dei Padri sinodali, ho già avuto modo di raccomandare
} 
Ojciec Święty przypomina, że przy innych okazjach podkreślał, iż katechumenat jako taki jest jedyny (chrzcielny), a więc zakorzeniony we chrzcie. W życiu jednak musi mieć charakter stały, „bowiem stała jest łaska [podkr. w tekście - W.G.] sakramentu małżeństwa, który właśnie jako łaska [podkr. w tekście - W.G.] jest owocem tajemnicy, której bogactwo musi być strzeżone i wspierane w sumieniu małżonków jako jednostek i jako pary. Chodzi w rzeczywistości o szczególne formy owej nieustającej cura animarum, która jest racją istnienia Kościoła i nas, pasterzy, w pierwszym rzędzie"10.

\section{Troska o sumienia zadaniem wszystkich wiernych}

Mówiąc o trosce o sumienia, papież Franciszek stwierdza, że nie może być ona obowiązkiem wyłącznie pasterzy, lecz - przy różnej odpowiedzialności i w różny sposób - jest misją wszystkich kapłanów i wiernych świeckich. Już Paweł VI wzywał do całkowitej wierności w celu zachowania regula fide $i^{11}$. Reguła ta, jak podkreślał, oświeca su-

l'impegno di un catecumenato matrimoniale [podkr. w tekście - W.G.], inteso come itinerario indispensabile dei giovani e delle coppie destinato a far rivvivere la loro coscienza cristiana, sostenuta dalla grazia dei due sacramenti, battesimo e matrimnio". Tamże; W adhortcji apostolskiej Amoris laetitia (n. 206) znalazł się następujący fragment pochodzący z Relacji końcowej XIV Nadzwyczajnego Zgromadzenia Ogólnego Synodu Biskupów z 2014 roku „Złożona rzeczywistość społeczna oraz wyzwania, przed jakimi stoi dziś rodzina, wymagają większego zaangażowania całej wspólnoty chrześcijańskiej w przygotowanie narzeczonych do małżeństwa. Trzeba przypomnieć o znaczeniu cnót. Wśród nich czystość jest cennym warunkiem autentycznego rozwoju prawdziwej miłości międzyosobowej. W odniesieniu do tej potrzeby Ojcowie synodalni byli zgodni, że istnieje konieczność większego zaangażowania całej wspólnoty, z podkreśleniem szczególnego znaczenia świadectwa samych rodzin, a także zakorzenienia przygotowania do małżeństwa w procesie inicjacji chrześcijańskiej, z zaakcentowaniem powiązania małżeństwa ze chrztem oraz innymi sakramentami [podkr. - W.G.]. Dostrzeżono także potrzebę specyficznych programów przygotowania do małżeństwa, które byłyby prawdziwym doświadczeniem uczestnictwa w życiu kościelnym i pogłębiałyby różne aspekty życia rodzinnego". Relatio Synodi (18.10.2014), http://archidiecezja.warszawska.p./ ksieza/dokumenty/stolica-apostolska/relatio-synodi (Dostęp 19.07.2016), n. 39.

${ }^{10}$ Franciscus, La cura della coscienza cristiana, s. 8.

${ }^{11}$ Paulus VI, Insegnamenti, t. 15, Città del Vaticano 1977, s. 663. 
mienie i nie może być zaciemniana czy wypaczona. $\mathrm{W}$ tym celu, głosił następca Jana XXIII, „,należy unikać przeciwnych skrajności - zarówno ze strony tego, kto powołuje się na tradycję dla usprawiedliwienia swojego nieposłuszeństwa najwyższemu Magisterium i Soborowi Powszechnemu, jak i ze strony tych, którzy odrywają się od humus kościelnego, niszcząc autentyczną doktrynę Kościoła; jedna i druga postawa ujawnia niewłaściwy i może nieświadomy subiektywizm, jeśli nie są, niestety, symptomem uporu, zaciętości, zaburzenia równowagi, które to postawy ranią serce Kościoła, Matki i Nauczycielki"12.

Wiara jest światłem, kontynuuje Ojciec Święty, która oświeca nie tylko teraźniejszość, lecz również przyszłość, a małżeństwo i rodzina są przyszłością Kościoła i społeczeństwa. „,Zymś więc koniecznym jest wspieranie stanu katechumenatu permanentnego [podkr. w tekście - W.G.], ażeby sumienie ochrzczonych było otwarte na światło Ducha. Zamiar przyjęcia sakramentu nie jest nigdy owocem działania automatycznego, ale zawsze owocem sumienia oświeconego przez wiarę, jako rezultat połączenia tego, co ludzkie, z tym, co Boże. W tym sensie związek małżeński można określić jako prawdziwy tylko wówczas, gdy ludzka intencja oblubieńców jest ukierunkowana na to, czego chcą Chrystus i Kościół"13. Aby uświadomić to coraz lepiej przyszłym małżonkom, stwierdza Mówca, potrzebny jest wkład nie tylko biskupów i kapłanów, lecz także innych osób zaangażowanych

${ }^{12}$ „Occorre evitare gli estremismi opposti , sia da parte di chi si appela a tradizione per giustuficare la propria disobbedienza al supremo Magistero e al Concilio ecumemnico, sia da parte di quanti si sradicano dall'humus ecclesiale corrompendo la genuina dottrina della Choiesa; enttrambi gli atteggiamenti sono segno di indebito e forse inconscio soggettivismo, quando non sia purtroppo di ostinazione, di caparbietà, di squilibrio; posizioni queste che feriscono al cuore la Chiesa, Madre e Maestra”. Paulus VI, Insegnamenti, t. 14, Città del Vaticano 1976, s. 500.

${ }^{13}$ „,È necessario pertanto favorire uno stato di catecumenato permanente [podkr. w tekście - W.G.], affinché la coscienza dei battezzati sia aperta alla luce delo Spirito. L'intenzione sacramentale non è mai frutto di un automatismo, ma sempre di una coscienza illuminata dalla fede, come il risultato di una combinazione tra umano e divino. In questo senso, l'unione sponsale può dirsi vera solo se l'intenzione umana degli sposi è orientata a ciò che vogliono Cristo e la Chiesa". FRANCISCUS, La cura della coscienza cristiana, s. 8 . 
w duszpasterstwo, duchownych i wiernych świeckich, współodpowiedzialnych za misję Kościoła ${ }^{14}$.

\section{Wymierzanie sprawiedliwości w sprawach małżeńskich sprawą sumienia}

Zwracając się do audytorów rotalnych, papież Franciszek zauważa, że ścisły związek zachodzący między sferą sumienia i dziedziną procesów małżeńskich, którymi zajmują się na co dzień, wymaga wystrzegania się tego, by wymierzanie sprawiedliwości sprowadzało się do zwykłej procedury biurokratycznej. Ulegnięcie takiej pokusie przez trybunały kościelne oznaczałoby sprzeniewierzenie się sumieniu chrześcijańskiemu. „Dlatego też postanowiłem, nadmienia Ojciec Święty, aby $\mathrm{w}$ postępowaniu w przypadku procesu skróconego nie tylko była lepiej uwydatniona rola nadzorcza biskupa diecezjalnego, ale także aby on sam, sędzia «urodzony» w powierzonym mu Kościele, osądzał w pierwszej instancji ewentualne przypadki nieważności małżeństwa”15.

W tym kontekście Papież akcentuje potrzebę zapobiegania temu, aby sumienie wiernych, którzy znaleźli się w trudnej sytuacji co do swojego małżeństwa, zamknęło się na działanie Łaski. Ten cel, dodaje (przywołując adhortację apostolską Amoris laetitia, n. 242) ${ }^{16}$ można

\footnotetext{
${ }^{14}$ Tamże.

${ }^{15}$ „Ecco perché, nella procedura del processus brevior, ho stabilio non solo che sia reso più evidente il ruolo di vigilanza del Vescovo diocesano, ma anche che egli stesso, giudice nativo nella Chiesa affidatagli, giudichi in prima istanza i possibili casi di nullità matimoniale”. Tamże; Zob. Papież FRANCISZEK, List apostolski motu proprio „Mitis Iudex Dominus Iesus”, Zasady proceduralne, tytuł V.

${ }^{16}$ „Ojcowie synodalni wskazali , że «szczególne rozeznanie jest niezbędne do duszpasterskiego towarzyszenia osobom żyjącym w separacji, rozwiedzionym i opuszczonym. Trzeba przede wszystkim wysłuchać i dowartościować cierpienie tych, którzy doświadczyli niesprawiedliwie separacji, rozwodu lub porzucenia albo zostali zmuszeni, wskutek maltretowania przez współmałżonka, do zerwania pożycia. Wybaczenie doznanej niesprawiedliwości nie jest łatwe, ale jest drogą, którą umożliwia łaska. Stąd wypływa konieczność duszpasterstwa pojednania i pośredniczenia także za pomocą wyspecjalizowanych ośrodków konsultacyjnych, które winny powstać w diecezjach». Jednocześnie «osoby rozwiedzione, które jednak nie zawarły nowego związku małżeńskiego, będące często świadkami wierności
} 
osiągnąć przez duszpasterskie towarzyszenie i rozeznawanie sumień i przez działalność naszych trybunałów. Dzieło to, stwierdza Mówca, winno być realizowane w sposób mądry i z poszukiwaniem prawdy tylko wówczas orzeczenie nieważności powoduje wyzwolenie sumień1 ${ }^{17}$.

Wyrażenie przez Papieża audytorom rotalnym wdzięczności za dobro, jakie czynią Ludowi Bożemu poprzez posługę sprawiedliwości, oraz zapewnienie o modlitwie i udzielenie błogosławieństwa kończy alokucję papieską.

\section{Zakończenie}

Kolejna, już piąta alokucja papieża Franciszka wygłoszona do Trybunału Roty Rzymskiej, poświęcona tym razem trosce najwyższego Pasterza Kościoła o chrześcijańskie sumienie, stanowi znaczący wkład Magisterium papieskiego w dzieło pogłębienia myśli Kościoła w przedmiocie miejsca i roli sumienia - zarówno sędziego kościelnego, rozstrzygającego sprawy o nieważność małżeństwa, jak i tych, których sprawy te dotyczą. W pewnej mierze Ojciec Święty nawiązuje - implicite - do nauczania Jana Pawła II o sumieniu, owym „sanktuarium człowieka”, zawartego w encyklice Veritatis splendor z 6 sierpnia 1993 roku $^{18}$.

Odnosząc się bezpośrednio do roli sędziów rotalnych, a pośrednio do wszystkich sędziów posługujących w trybunałach kościelnych (regionalnych, międzydiecezjalnych, metropolitalnych i diecezjalnych),

małżeńskiej, trzeba zachęcać do znajdywania w Eucharystii pokarmu, który wspiera je w ich stanie. Lokalna wspólnota i duszpasterze winni towarzyszyć tym osobom z troską, zwłaszcza dzieciom lub gdy są w sytuacji poważnego ubóstwa» (Relatio Synodi (18.10.2014), dok. cyt., n. 50). Rozpad małżeństwa staje się bardziej traumatyczny i bolesny, gdy mamy do czynienia z ubóstwem, bo jest znacznie mniej środków na przeorientowanie życia. Osoba uboga, która traci ochronne środowisko rodzinne, jest podwójnie narażona na porzucenie i wszelkiego rodzaju zagrożenia dla swej integralności”. Ojciec Święty Franciszek, Posynodalna Adhortacja Apostolska „Amoris laetitia”, n. 242.

${ }^{17}$ Franciscus, La cura della coscienza cristiana, s. 8.

${ }^{18}$ JAN PAWEŁ II, Encyklika „Veritatis splendor”, w: Encykliki Ojca Świętego Jana Pawła II, Kraków 2005, w szczególności rozdz. II: Sumienie a prawda, s. 767-776. 
papież Franciszek uznaje ich za ekspertów od sumienia wiernych, a ich posługę nazywa wymownie „posługą pokoju sumień”, którą powinni wykonywać z pełną sumiennością.

Bardzo trafne wydaje się zwrócenie uwagi przez następcę Benedykta XVI na ścisły związek zachodzący między pewnością moralną sędziego (wymaganą do wydania wyroku) a jego sumieniem. Wolno w tym miejscu przypomnieć, że pewności moralnej towarzyszącej wydaniu wyroku przez sędziego kościelnego wymaga kan. $1608 \$ 1$ KPK, stwierdzając jednocześnie, że powinien ją czerpać „ex actis et probatis” (\$2); dowody zaś „ma oceniać $w$ swoim sumieniu [podkr. W.G.], z zachowaniem przepisów ustawy o skuteczności niektórych dowodów” (\$ 3). Mówiąc o wsparciu sumienia sędziowskiego przez Ducha Świętego i o Jego ,świetle”, Franciszek jednoznacznie daje do zrozumienia, że przed powzięciem decyzji sędzia powinien o to światło prosić, odwołując się do modlitwy Adsumus ${ }^{19}$.

Na kanwie przypomnienia przez Ojca Świętego zasady pewności moralnej u sędziego wydającego wyrok w sprawie nullitatis matrimonii można pytać: Czy sędziowie kościelni wydając wyrok za nieważnością małżeństwa wystarczająco zwracają uwagę na uzyskanie pewności moralnej co do nieważności małżeństwa ? Czy przypadkiem nie mylą pewności moralnej z osobistym przekonaniem? ${ }^{20} \mathrm{~W}$ art. 12

${ }^{19} \mathrm{~W}$ modlitwie tej szczególnego znaczenia w ustach sędziego nabierają następujące słowa: ,[...] ut et hic a Te in nullo dissentiat sententia nostra”.

${ }^{20}$ Warto w tym miejscu przytoczyć wypowiedź abp. Zenona Grocholewskiego z 1999 roku, ówczesnego sekretarza Sygnatury Apostolskiej, który na pytanie, czym jest pewność moralna sędziego, odpowiedział: „Pewność moralna jest pojęciem wypracowanym na terenie prawa kanonicznego w wieku XX, do czego przyczynił się bardzo Pius XII. Jest to rzecz bardzo oryginalna. Ja również napisałem na ten temat artykuł, który został przetłumaczony na kilka języków. Trudno w kilku słowach wytłumaczyć to zagadnienie, ale spróbuję. Pewność moralna to nie jest pewność absolutna, jednak wyklucza wszelka poważna wątpliwość [podkr. - W.G.]. Pewność moralna musi być oparta na dokumentach i racjach obiektywnych. Nie może to być subiektywne przekonanie kogoś [podkr. - W.G.]. Nie można się domagać od sędziego pewności absolutnej, bo takiej pewności nigdy nie da się osiągnąć. Jest to przecież ludzkie podchodzenie do problemu. Myślę, że pewność moralna to jeden $\mathrm{z}$ takich elementów, które prawo kanoniczne ma do zaoferowania prawu 
Zasad proceduralnych motu proprio Mitis Iudex czytamy: „Do osiągnięcia pewności moralnej, wymaganej przez prawo, nie wystarczy przeważające znaczenie dowodów i poszlak, ale wymaga się, aby została wykluczona jakakolwiek roztropna pozytywna wątpliwość popełnienia błędu tak co do prawa, jak i co do ustaleń faktycznych, chociaż nie wyklucza się zwykłej możliwości czegoś przeciwnego".

W alokucji Franciszkowej godny uwagi jest wątek ukazujący rolę sumienia u narzeczonych sposobiących się do zawarcia małżeństwa. Znaczące jest tutaj m.in. odwołanie się do pierwszych pięciu rozdziałów adhortacji apostolskiej Amoris laetitia. Ma to na celu przekonanie potencjalnych kandydatów do małżeństwa, że pakt małżeński kryje w sobie prawdziwe bogactwo i stanowi szczególną radośćc ${ }^{21}$.

świeckiemu. Byłem kiedyś na międzynarodowym kongresie prawa świeckiego, brałem udział w okrągłym stole i pamiętam, że - mówiąc o pewności moralnej wzbudziłem wielkie zainteresowanie, do tego stopnia, że nawet po zakończeniu kongresu jeszcze wielu z biorących w nim udział prawników zwracało się do mnie z prośbą o wyjaśnienie tego pojęcia, proponując mi nawet napisanie artykułu w czasopiśmie z zakresu prawa porównawczego. Uważali, że warto podzielić się wiedzą na ten temat z przedstawicielami prawa świeckiego". Mieć pewność moralną. Z abp. Zenonem Grocholewski rozmawia Anna Błaszczak, „Niedziela” 42 (1999), nr 52, s. 23.

${ }^{21} \mathrm{~W}$ pięciu pierwszych rozdziałach (nn. 8-198) Amoris laetitia nie brak bogatych w treść stwierdzeń, które powinny „ocalić młodych ludzi przed ogłuszającym zgiełkiem i hałasem tego, co nietrwałe, co skłania do ich rezygnowania z podejmowania stałych i pozytywnych zobowiązań dla dobra indywidualnego i zbiorowego". Można tutaj przytoczyć m.in. następujące fragmenty wymienionej adhortacji apostolskiej: „Para, która kocha i rodzi życie, jest prawdziwą żywą [...] «figurą», zdolną ukazać Boga Stwórcę i Zbawiciela” (n. 11); , Musimy być wdzięczni za fakt, że większość ludzi ceni relacje rodzinne, które pozwalają trwać w czasie i zapewniają drugiej osobie szacunek” (n. 38); „Nikt nie może myśleć, że osłabienie rodziny jako społeczności naturalnej, opartej na małżeństwie jest czymś, co społeczności przynosi korzyść, Jest wręcz odwrotnie: to wyrządza szkodę dojrzewaniu ludzi ” (n. 52); „Niech Nazaret przypomni nam, czym jest rodzina, czym jest komunia miłości, jej surowe i proste piękno, jej święty i nienaruszalny charakter” (n. 66); „Sakrament małżeństwa nie jest umową społeczną, pustym rytuałem lub jedynie zewnętrznym znakiem zaręczyn. Sakrament jest darem dla uświęcenia i zbawienia małżonków” (n. 72); „,[Miłość małżeńska] jest to miłość, która jednoczy małżonków, uświęcona, ubogacona i oświecona łaską sakramentu małżeństwa. Jest to «zjednoczenie woli», duchowe i ofiarne, które jednak zawiera w sobie czułość przyjaźni i namiętność erotyczną, chociaż 
Akcentując potrzebę podejmowania katechumenatu małżeńskiego, Franciszek upatruje w tej formie przygotowania do małżeństwa m.in. ochronę chrześcijańskiego sumienia. Dostrzega jednocześnie trud i wysiłek biskupów oraz pozostałych duszpasterzy w urzeczywistnianiu tego przedsięwzięcia. Tego rodzaju katechumenat, rozumiany jako prowadzenie młodych chrześcijan - na bazie chrztu - do ożywienia ich sumienia, stanowiłby instytucję pozwalającą na solidne przygotowanie do małżeństwa. Ojciec Święty zdaje sobie sprawę z tego, że z natury swojej katechumenat jest tylko jeden: oparty na sakramencie chrztu. Gdy chodzi natomiast o katechumenat małżeński, to miałby służyć pogłębianiu świadomości ochrzczonych w perspektywie małżeństwa. W adhortacji apostolskiej Amoris laetitia wspomina się o rodzaju „inicjacji” do sakramentu małżeństwa, „który zapewni im [młodym - W.G.] niezbędne elementy, aby mogli go przyjąć z najlepszą dyspozycją i rozpocząć życie rodzinne z pewną solidnością"22.

jest w stanie przetrwać nawet wtedy, gdy uczucia i namiętność ulegają osłabieniu” (n. 120); „,Małżeństwo jest ikoną miłości Boga do nas” (n. 121); „,Oprócz miłości. która jednoczy nas z Bogiem, miłość małżeńska jest «największą przyjaźnią»" /św. Tomasz z Akwinu/ (n. 123); , Małżeństwo jest także przyjaźnią, która zawiera cechy właściwe namiętności, ale zawsze jest nakierowana na jedność coraz mocniejszą i intensywniejszą. Bo «nie zostało ustanowione jedynie w celu zrodzenia dzieci», lecz aby «wzajemna miłość małżonków, okazywana we właściwym porządku, rozwijała się i dojrzewała» /Konstytucja Gaudium et spes Soboru Watykańskiego II, n. 50/ (n. 125)”; „Chcę powiedzieć ludziom młodym, że nic z tego [z radości - W.G.] nie ulega osłabieniu, gdy miłość przyjmuje formę instytucji małżeństwa” (n. 131); ,Małżeństwo wykracza poza wszelką przelotną modę i trwa. Jego istota jest zakorzeniona w samej naturze osoby ludzkiej oraz jej charakterze społecznym” (n. 131); „,Miłość przyjaźni łączy wszystkie aspekty życia małżeńskiego i pomaga członkom rodziny iść naprzód na każdym jej etapie” (n. 133); ,Żadną miarą nie możemy rozumieć erotycznego wymiaru miłości, jako dozwolonego zła lub jako ciężaru, który trzeba tolerować dla dobra rodziny, ale jako dar Boga, który upiększa spotkanie małżonków” (n. 152); „Ważne jest, by jasno odrzucić wszelkie formy podporządkowania seksualnego” (n. 156); ,„Rodzina jest nie tylko środowiskiem zrodzenia, ale także przyjęcia życia jako daru, który pochodzi od Boga. Każde nowe życie «pozwala nam odkryć najbardziej bezinteresowny wymiar miłości, nieustannie nas zadziwiający» /katecheza Franciszka z 11.02.2015/ (n. 166)”.

${ }^{22}$ Ojciec Święty Franciszek, Posynodalna Adhortacja Apostolska „Amoris laetitia”, n. 207; W wymienionej adhortacji pada ważne stwierdzenie: „Zarówno 
Cenna jest następnie konstatacja zawarta w alokucji Franciszka, w myśl której troska o sumienia należy do wszystkich chrześcijan skupionych w Kościele katolickim; należy ją realizować w całkowitej wierności „regule wiary”23. Jest to wyraz pośredniego nawiązania do encykliki Jana Pawła II Veritatis splendor, gdzie stwierdza się: „W kształtowaniu sumienia bardzo pomaga chrześcijanom Kościół i Jego Magisterium, o czym pisze Sobór: «Chrześcijanie zaś w kształtowaniu swego sumienia powinni pilnie baczyć ma święta i pewną naukę Kościoła» (Deklaracja o wolności religijnej Dignitatis humanae, n. 14)" 24 .

Na uwagę zasługuje wreszcie znaczące przypomnienie Papieża, że między sferą sumienia a dziedziną procesów małżeńskich zachodzi ścisły związek, co jednoznacznie oznacza stanowcze zdezawuowanie jakiejkolwiek próby rozpoznawania i rozstrzygania tak doniosłych spraw na płaszczyźnie „Zwykłej procedury biurokratycznej”.

przygotowanie bliższe, jak i towarzyszenie dłuższe, powinny przekonać narzeczonych, aby nie postrzegali pobrania się jako końca drogi, ale aby podjęli małżeństwo jako powołanie, które wymaga stanowczej i realistycznej decyzji, aby wspólnie przejść przez wszystkie próby i chwile trudne. Duszpasterstwo przedmałżeńskie i duszpasterstwo małżeństw powinny być przede wszystkim duszpasterstwem więzi, gdzie wznoszone są elementy, które pomagają zarówno w dojrzewaniu miłości, jak i w przezwyciężaniu chwil trudnych”. Tamże, n. 211.

${ }^{23}$ Starożytny termin regula fidei albo regula veritatis (reguła wiary) jako termin techniczny został wprowadzony przez św. Ireneusza. Regula fidei to miara, prawidło, dzięki któremu można zweryfikować, czy subiektywnie przyjęta treść wiary jest zgodna z wiarą prawdziwą. Chodzi więc o kryterium prawdziwości wyznawanej wiary. Regula fidei, na którą powoływano się w czasie prowadzenia sporów doktrynalnych, była więc normą (kanonem), kryterium zgodności z prawdą Ewangelii. Regułę wiary identyfikowano z normami przekazanymi w Ewangelii oraz z nauką przekazaną przez Apostołów (Tradycją apostolską). Reguła wiary nie jest więc identyczna z jakimś określonym tekstem wyznania wiary, ale z całością wyznawanej w Kościele wiary, którą da się wyrazić w prostych słowach. Reguła ta pochodzi od Boga (regula Dei) i jest sumą tego, co Chrystus powierzył swoim Apostołom. Zob. M. Fiedrowicz, Teologia Ojców Kościoła. Podstawy wczesnochrześcijańskiej refleksji nad wiarą, Kraków 2009, s. 203-210.

${ }^{24}$ JAN PAWEŁ II, Encyklika „Veritatis splendor” n. 64. 
Niewątpliwie przemówienie Franciszka do Roty Rzymskiej z 29 stycznia 2018 roku znacząco wpisuje się w długi już ciąg nauczania papieskiego podejmowanego w takiej właśnie formie.

\section{The ministry of a judge as a ministry of conscience. The speech of Pope Francis to the Roman Rota of 29 January 2018}

In the papal annual speech addressed to the Tribunal of the Roman Rota on January 29, 2018, Francis raised the subject of an important aspect of a judges' ministry, which is the central place of conscience of each judge and conscience of those whose cases he deals with. As emphasized by the speaker, the judges' activity is also seen as a ministry of conscience and requires performing it with full conscientiousness.

Presenting and commenting on the papal speech, the author focuses on the following issues present in the Francis' allocation: a judge as an expert on conscience, the role of conscience in brides' choices, the need for marital catechumenate (based on the sacrament of baptism), conscientious obedience of all the faithful, administration of justice in matrimonial matters a matter of conscience.

Undoubtedly, the speech of Francis to the Roman Rota of 29 January 2018 is a significant part of the long course of papal teaching undertaken in this form.

SŁowA KLUCzowe: Franciszek; Rota Rzymska; sędzia; małżeństwo; sumienie; katechumenat.

KeYwORDs: Francis; Roman Rota; judge; marriage; conscience; catechumenate.

\section{Nota O Autorze:}

Ks. Prof. Dr Hab. Wojciech Góralski - kierownik Zakładu Kościelnego Prawa Rodzinnego na Wydziale Prawa Kanonicznego UKSW, redaktor naczelny kwartalnika „Ius Matrimoniale”, sędzia diecezjalny w Sądzie Biskupim w Płocku, wiceprzewodniczący Stowarzyszenia Kanonistów Polskich. 